\title{
Sykehusrutiner og traumatisering av pasienter
}

\author{
En morgen i august for drøyt tre år siden ringte telefonen. Det var en kontoransatt på sykehuset der jeg var \\ operert for prostatakreft noen uker tidligere.
}

En stemme informerte om at jeg måtte ta med meg en pårørende og møte til samtale på avdelingen klokken 13 dagen etter. Jeg spurte om hun kunne si noe om hva samtalen skulle handle om. Det kunne hun ikke. Jeg ba om å få en kort samtale med en av legene for å få vite noe om hvor alvorlig informasjonen kunne være. Svaret var at det ikke var mulig å få snakke med noen av legene og at jeg måtte komme dagen etter sammen med en pårørende.

Jeg var klar over at en patolog skulle gå gjennom det som var blitt fjernet ved operasjonen. Tiden som var gått, passet med at det kunne foreligge en patolograpport.

Fra da av slo det irrasjonelle inn. Jeg ble mer og mer sikker på at det var en svært alvorlig beskjed som ventet dagen etter. Dødsangsten tok tak. Jeg skalv meg igjennom de neste 28 timene. Frøs i tykke klær en varm sommerdag og en hel sommernatt.

Beskjeden dagen etter var ikke så ille som angsten hadde skreket om, og slett ikke fatal. Tumoren var noe større enn de først hadde trodd og informert meg om. Den hadde vokst ut av prostatakapselen, noe som gjorde det nødvendig med stråleterapi. Ikke en god beskjed, men helt til å leve godt med.

Dette døgnet førte til sterke og langvarige traumereaksjoner. Mer enn tre år etter er jeg fremdeles ute av balanse. Dette

\section{«Dødsangsten tok tak. Jeg skalv megigjennom de neste 28 timene»}

har vært så vanskelig å leve med at jeg måtte søke hjelp. Har prøvd med mindfulness og to varianter av traumeorientert terapi - uten særlig effekt så langt. Skrekken sitter i. Det er det døgnet for tre og et halvt år siden som kommer tilbake i drømmer og når jeg våkner om natten. Hele tiden bruker jeg mye energi på å holde det på avstand, er i konstant beredskap mot minnene og tankene.
Jeg er helt sikker på at ikke alle reagerer som meg i en tilsvarende situasjon. Like sikker er jeg på at jeg ikke er den eneste.

Et viktig spørsmål: Er det nødvendig at sykehus har rutiner som kan være potensielt traumatiserende for pasientene? Er det noe som taler sterkt imot å formidle denne typen budskap på en måte som gir nok informasjon til å forebygge alvorlige angstreaksjoner? Det ville antakelig bety noe bruk av legers tid til å snakke i telefonen med pasienter som ber om det. Et par minutter ville vært tilstrekkelig for meg før den oppsatte samtalen dagen etter. Det ville være svært godt anvendte ressurser.

\section{Knut Brandsborg}

knut.brandsborg@statped.no

Knut Brandsborg (f. 1950) er psykologspesialist.

Mottatt 23.1.2015 og godkjent 25.2. 2015. Redaktør: Are Brean.

\section{Kommentar}

\section{Traumatisering av pasienter i sykehus}

Psykologspesialist Knut Brandsborg forteller om sine erfaringer fra da han ble oppringt fra et sykehus etter en operasjon for prostatakreft. Hans historie illustrerer hvordan pasienter kan påføres unødvendige helseproblemer når kommunikasjonen er dårlig.

En kreftoperasjon er ikke noen bagatell. Dette må man ta hensyn til når man skal informere pasienten om spredning eller komplikasjoner. I henhold til pasientens beskrivelse har sykehuset gjort uheldige valg ved å la en kontoransatt ringe og be ham komme sammen med pårørende - uten at lege på det tidspunkt er tilgjengelig for spørsmål. Pasienten vil selvsagt oppfatte at det foreligger en alvorlig tilstand og kan lett få katastrofetanker.

Det er ofte vanskelig å informere om en kreftdiagnose. Mange får informasjon per telefon, i sykehuskorridoren eller på visitten
(1). Når pasienten er innlagt i sykehus, bør informasjon gis i enerom, eventuelt med pårørende til stede. Når pasienten har reist hjem, kan en telefonsamtale være det beste alternativet. Dette krever både kunnskap om tilstanden og evne til kommunikasjon - og da trengs legen. Også i en telefonsamtale kan man forberede pasienten, informere om hovedfunnet, invitere til snarlig konsultasjon og eventuelt berolige.

En kreftdiagnose er en potensielt traumatiserende hendelse. Risikoen for posttraumatiske symptomer avhenger blant annet av graden av opplevd trussel, varigheten av dette, liten opplevd kontroll og personlig sårbarhet. Trusselen kan oppleves som alvorlig uten at det foreligger objektiv fare.

Det bedre å forebygge enn å behandle. Den aktuelle pasienten hadde symptomer tre år etter hendelsen på tross av psykologisk behandling. Det kan skyldes personlig sårbarhet, at den psykologiske behandlingen ikke var adekvat eller nye belastninger. Man behøver ikke være redd for å gi saklig informasjon om kreft hvis rammevilkårene er gode og man også tar hensyn til pasientenes opplevelser - og støtter dem som får sterkere krisereaksjoner.

Noen vil kanskje tenke at helsepersonell tåler sykdom bedre enn andre. Men kanskje er personlig sårbarhet en medvirkende årsak til at man velger et hjelperyrke. Det finnes eksempelvis studier som har vist større sårbarhet (nevrotisisme) hos leger enn hos polititjenestemenn $(2,3)$. Det er viktig å behandle kolleger som andre pasienter, både når det gjelder informasjon og oppfølging.

Til spørsmålet om det er nødvendig at 